TECHNICAL TRANSACTIONS 10/2017

CZASOPISMO TECHNICZNE 10/2017

MECHANICS

DOI: $10.4467 / 2353737$ XCT.17.181.7289

\author{
Karolina Głogowska (k.glogowska@pollub.pl) \\ Łukasz Majewski \\ Department of Technology and Polymer Processing, Mechanical Engineering Faculty, \\ Lublin University of Technology
}

\title{
THE EFFECT OF SELECTED NATURAL FILLERS ON THE MECHANICAL PROPERTIES OF LOW-DENSITY POLYETHYLENE
}

\author{
WPEYW WYBRANYCH NAPEŁNIACZY NATURALNYCH NA WŁAŚCIWOŚCI \\ MECHANICZNE POLIETYLENU MAŁEJ GĘSTOŚCI
}

\begin{abstract}
The popularity of using natural waste products in different branches of industry, including polymer processing, results from the emphasis of international nature conservation organizations on ecological and environmental problems, such as recycling, storage and the disposal of waste products. This paper investigates the effect of two natural fillers: wheat bran and pumpkin seeds obtained from food industry waste products, on selected mechanical properties of LDPE molded pieces. The polymer blends are examined with respect to their basic mechanical properties and microstructure.
\end{abstract}

Keywords: natural waste material, mechanical properties, wheat bran, pumpkin seeds

\section{Streszczenie}

Popularyzacja wykorzystania odpadów naturalnych w różnych gałęziach przemysłu, m.in. w przetwórstwie tworzyw, związana jest z naciskiem światowych organizacji odpowiadających za ochronę środowiska na kwestie ekologiczne, takie jak recykling oraz składowanie i utylizacja odpadów. W artykule przedstawiono badania wpływu dwóch napełniaczy, otrębów pszennych oraz lusek pestek dyni, stanowiących odpady produkcyjne przemysłu spożywczego, na wybrane wlaściwości mechaniczne wyprasek wtryskowych z PE-LD. Przeprowadzono badania podstawowych właściwości wytrzymałościowych oraz dokonano analizy struktury mikroskopowej otrzymanych kompozycji polimerowych.

Słowa kluczowe: odpady naturalne, właściwości mechaniczne, otręby pszenne, pestki dyni 


\section{Introduction}

In the recent years, polymer blends containing natural fillers have been more and more widely used in the processing industry, particularly in polymer processing. Polymer blends have unique properties, which is why they are used in different branches of industry. In order to obtain products with the required functional properties, polymers are physically modified by the use of fillers. The properties of the thereby produced composite material are significantly affected by interactions between the polymer matrix and the filler. In some cases, particularly when their concentration is low, powdered fillers can act as heterogeneous nucleates in the polymer crystalline phase [1-4].

The physical modification of polymers is usually done using solid substances with a relevant degree of refinement. These substances predominantly include dyes, pigments, organic and non-organic fillers, reinforcing agents - usually fibrous and powdered substances, glass balls or their blends, the so-called hybrid fillers [5]. Modifiers can enhance some physical and chemical properties, but at the same time, other properties may decrease. This results from the differences in the interaction between polymer particles and the substance being modified. In the recent years, polymers have been more and more often modified using either micro-, submicron- and nanorefined materials, or materials, which naturally occur in such forms [6]. Previous experimental results demonstrate that it is a very promising, fast developing field of knowledge, which opens up new possibilities, impossible to explore using traditional modification methods [5].

There are numerous methods of classifying physical modification by fillers [7]. It seems, however, that the most effective way to classify filler-induced physical modification of plastics is according to the filler function and particle size. The polymer matrix keeps the blend together due to the adhesion of elementary particles of the filler to the polymer. Smaller particles bond more easily and form a more durable structure $[8,9]$.

The aim of the study was to determine the effect of powdered fillers obtained from renewable resources, such as wheat bran and pumpkin seed hulls, on the mechanical properties of low-density polyethylene (LDPE) filled with these natural fillers. In particular, the study examined the relationships between the basic strength properties of the produced injection molded pieces and filler contents. In addition, it attempted to explain the observed phenomena via an analysis of the matrix-filler system.

\section{Experimental}

\subsection{Test stand}

The tests were performed using the ARBURG ALLROUNDER 320C single-screw injection molding machine (Loßburg, Germany), provided with a two-cavity mold for manufacturing standard specimens in compliance with ISO 527-1:2012.

The static tensile tests were performed on the produced composite molded pieces using a standard testing machine, Z010 AllroundLine from Zwick Roell (Ulm, Germany). The 
Z010 testing machine has a maximum tensile force of up to $10 \mathrm{kN}$ and a tensile rate up to $2000 \mathrm{~mm} / \mathrm{min}$.

Hardness measurements were conducted by the Shore method using the ART.13 hardness tester manufactured by Affri System Hardness Testers (Induno Olona, Italy). This hardness tester has a unique digital system for data processing from the gauge head. It is also provided with an LCD reader for all Shore and automatic detection of the probe and hardness scale.

The examination of the morphology of the specimen cross sections was performed using the Nikon Eclipse LV100ND microscope (Warsaw, Poland), equipped with the DS-U3 camera and NIS-Elements AR 4.20.00 software.

\subsection{Materials}

The study was conducted using powdered low-density polyethylene, DOWLEX ${ }^{\circledast}$ (LDPE) 2631.10EU, manufactured by The Dow Chemical Company (Schkopau, Germany). This plastic is used for producing a plastic film by blow molding, casting, extrusion molding with a coating, rotational casting and injection molding. DOWLEX ${ }^{\odot}$ is used in many branches of the industry, including the manufacture of industrial, food and medical packaging. Some of its modifications are also used for manufacturing sanitary products, consumer products as well as dairy products. Table 1 lists the properties of the tested polymer after the specifications provided by the manufacturer.

Table 1. Basic properties of the polymer used in the tests

\begin{tabular}{|l|c|}
\hline \multicolumn{1}{|c|}{ Property } & Value \\
\hline Density $23^{\circ} \mathrm{C},\left[\mathrm{kg} / \mathrm{m}^{3}\right]$ & 935 \\
Melt mass flow rate $\left(230^{\circ} \mathrm{C} ; 2.16 \mathrm{~kg}\right),[\mathrm{g} / 10 \mathrm{~min}]$ & 7 \\
Tensile stress at yield, $[\mathrm{MPa}]$ & 17.8 \\
Tensile strain at yield, $[\%]$ & 419 \\
Shore hardness, $\left[{ }^{\circ} \mathrm{Sh} \mathrm{D}\right]$ & 56 \\
$\mathrm{HDT}$ temperature, $\mathrm{B}(0.45 \mathrm{MPa})\left[{ }^{\circ} \mathrm{C}\right]$ & 52 \\
Vicat softening temperature $\left(\mathrm{A} 120\left(120^{\circ} \mathrm{C} / \mathrm{h} 10 \mathrm{~N}\right)\right.$, & 115 \\
{$\left[{ }^{\circ} \mathrm{C}\right]$} & 124 \\
Melting temperature, $\left[{ }^{\circ} \mathrm{C}\right]$ & \\
\hline
\end{tabular}

One of the fillers used in the tests was wheat bran (WB), which is the outer layers of the wheat grain. Bran is a byproduct of the milling process in which wheat grain is conversed to clean, white flour. It has the shape of thin flakes, which are several millimeters in size. The main ingredient of wheat bran is raw fiber comprising a sum of fibrous substances, such as cellulose, lignin and hemicellulose; apart from that, wheat bran contains phytic acid, oligosaccharides and non-starch polysaccharides as well as small amounts of fats and proteins [10]. The hardness of WB is approx. $0.35 \mathrm{~g} / \mathrm{cm}^{3}[10]$.

The other natural fillers used in the tests were pumpkin seed hulls obtained from a company dealing with the purification and sales of pumpkin seeds (Fig. 2a). Hulls (Fig. 2b) are a waste material produced by the mechanical hulling and purification of pumpkin seeds. The main component of pumpkin seed hulls are mixtures of polysaccharide substances (cellulose, hemicellulose, pectin, gum, slime mold) and non-polysaccharide substances (lignin) [11]. 
a)

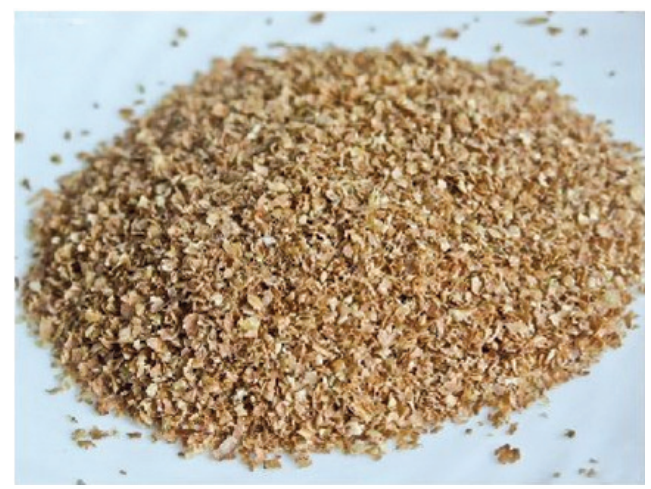

b)

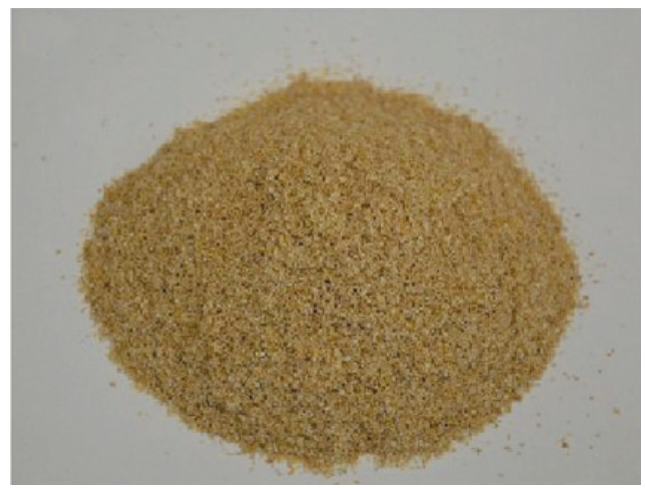

Fig. 1. General view of: a) coarse bran, b) finely ground bran

a)

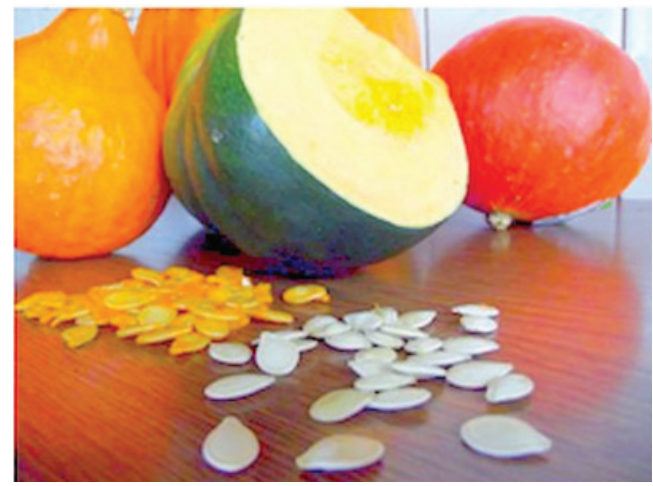

b)

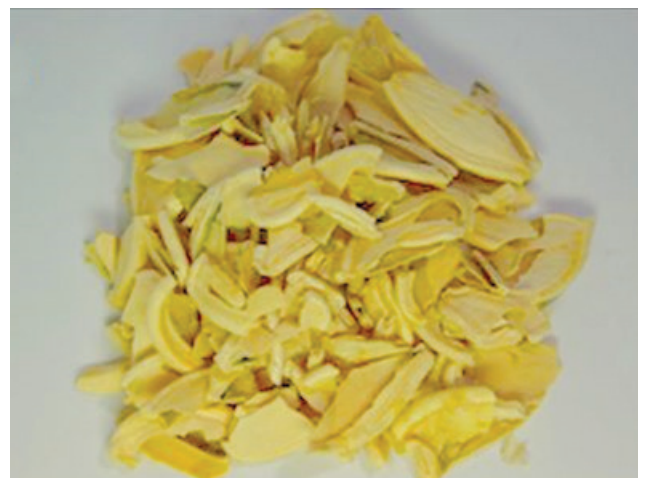

Fig. 2. General view of: a) pumpkins and their seeds and b) pumpkin seed hulls

\subsection{Tested parameters}

Given the objective of the study, a set of key parameters was established to describe the investigated processes, including the preparation of injection molded pieces, tensile tests as well as hardness measurements. These parameters were divided into the following groups:

Direct factors:

- maximum tensile force, $F_{Z} N$,

- yield point, $F_{R} N$,

- change in the measuring length at yield $\Delta l_{R}, \mathrm{~mm}$,

- change in the measuring length at maximum tensile force $\Delta l_{Z}, \mathrm{~mm}$,

- specimen size, $\mathrm{mm}$.

Indirect factors:

- cross-sectional area of the specimen, $A, \mathrm{~mm}^{2}$.

Resulting factors:

- Young's modulus E, MPa, 
- maximum tensile stress $\sigma_{z^{\prime}} \mathrm{MPa}$,

- tensile stress at yield $\sigma_{r}, \mathrm{MPa}$,

- tensile strain $\varepsilon_{z^{\prime}} \%$,

- tensile strain at yield, $\varepsilon_{r} \%$,

- hardness $H$, ${ }^{\circ} \mathrm{ShD}$.

Variables:

- filler content in the specimen: 5, 10 and $15 \mathrm{wt} \%$.

Constant factors:

- filler grain diameter: $0.4-0.6 \mathrm{~mm}$,

- temperature of the plasticizing unit of the injection molding machine in particular zones, $t_{\mathrm{I}}-130^{\circ} \mathrm{C}, t_{\mathrm{II}}-135^{\circ} \mathrm{C}, t_{\mathrm{III}}-140^{\circ} \mathrm{C}, t_{\mathrm{IV}}-150^{\circ} \mathrm{C}$,

- temperature of the injection mold, $t_{f}=30^{\circ} \mathrm{C}$,

- injection pressure, $p=100 \mathrm{MPa}$,

- polymer injection time, $T_{w}=2 \mathrm{~s}$,

- polymer plasticization time in the plasticizing unit, $T_{u}=4 \mathrm{~s}$,

- polymer cooling time in closed mold cavity, $T_{c}=20 \mathrm{~s}$,

- specimen tension time, $v=100 \mathrm{~mm} / \mathrm{min}$.

Disturbing factors:

- electric voltage: $219-241 \mathrm{~V}$,

- relative air humidity: 55-65\%,

- ambient temperature: $20-24^{\circ} \mathrm{C}$.

The results demonstrate that the disturbing parameters have a negligible effect on the measurements, and can thus be omitted in the results discussion.

\section{Methods}

Wheat bran was first ground using a grinding mill. After that, fractions with different grain sizes were separated using sieves with mesh sizes of $0.4 \mathrm{~mm}$ and $0.6 \mathrm{~mm}$. This led to the production of one fraction with its grain size ranging between $0.4 \mathrm{~mm}$ and $0.6 \mathrm{~mm}$. The pumpkin seed hull filler was prepared in a similar way.

Prior to starting the injection molding machine, a blend of the low-density polyethylene and the filler was prepared. $500 \mathrm{~g}$ of the polymer was mixed with the tested filler content with the addition of adhesion-promoting carbofunctional silane marketed under the name of aminopropyltriethoxysilane [12]. The materials were mixed, and the produced polymer blend was fed into the hopper of the injection molding machine. The molded pieces produced during the first 10 cycles of the injection molding process were rejected. Only successively produced molded pieces were used as test specimens. The injection molding process was continued until the plasticizing unit of the machine was completely empty. After that, the hopper was loaded with another dose of the prepared mixture, this time with another tested filler content and grain size.

The use of wheat bran and pumpkin seed hulls (and many other natural materials) as polymer fillers means that the processing must be conducted at relatively low 
temperatures due to the thermal decomposition of organic substances and the intensive liberation of gases.

Static tensile tests were performed using the testing machine on 10 injection molded pieces in compliance with the ISO 527-1:1998 standard [13].

Hardness measurements were conducted in accordance with the procedure described in the ISO 527-1:2012 standard [14]. Twenty measurements were made on 10 different molded pieces.

\section{Results and discussion}

\subsection{Strength tests}

The static tensile test results are given in the form of diagrams in Figures 3 through 8 . The diagrams illustrate the relationships between the mean values of Young's modulus E, tensile strength, tensile stress at yield, tensile strain at the tensile strength and tensile strain at yield versus the filler contents in the tested injection molded pieces.

The relationships between Young's modulus and the filler type and content are illustrated in Fig. 3. The values of Young's modulus of the test specimens increase with increasing filler content, irrespective of the filler type. The maximum values of this parameter are $452 \mathrm{MPa}$ (wheat bran) and $427 \mathrm{MPa}$ (pumpkin seed hulls), which is equal to an increase by $23.49 \%$ and $16.66 \%$, respectively, compared to the initial value. Both types of filler, wheat bran and pumpkin seed hulls, significantly increase the rigidity of the tested injection molded pieces, which results from constraining the movement of polymer chains due to the presence of the filler. Similar observations about the relationship between Young's modulus and natural filler content were made in studies in which the following were used as fillers: rape straw [15], leaves [16], nutshells [17], oat hulls [18], wood powder [19] and switchgrass [20].

The relationships between the tensile strength and the filler type and content are shown in Fig. 4. The tensile strength of polyethylene filled with wheat bran and pumpkin seed hulls is lower than that of unfilled polyethylene in the entire tested range of filler content. Irrespective of the applied filler type, the addition of the lowest tested filler content ( $5 \mathrm{wt} \%$ ) leads to a decrease in the tensile strength. The lowest tensile strength of the specimens is observed at $15 \mathrm{wt} \%$ filler content. The tensile strength of the specimens is the same for both filler types $-1.35 \mathrm{MPa}$, which is equal to a $10.11 \%$ decrease in its initial value. The mechanical properties of composite materials depend on the filler's ability to integrate into the polymer microstructure. A survey of the literature on the subject reveals that the properties of composite materials can be enhanced by, among others, the optimization of amount, size, distribution and shape of the filler grain. A similar pattern of variations in the tensile strength of injection molded pieces was observed in other research studies on fillers obtained from renewable sources of energy, such as peanut shells [17], wood flour [21] and carbon filler Shungite III [22]. 


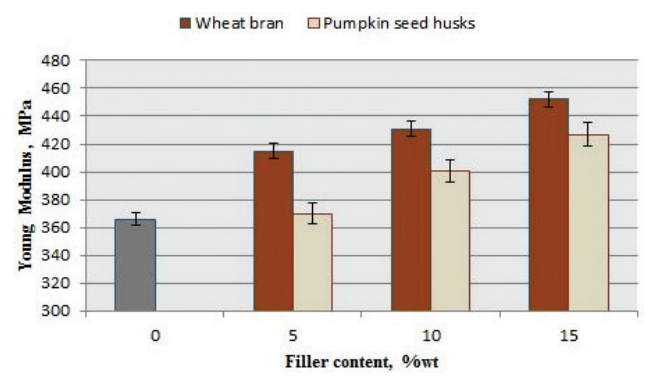

Fig. 3. Young's modulus versus filler content

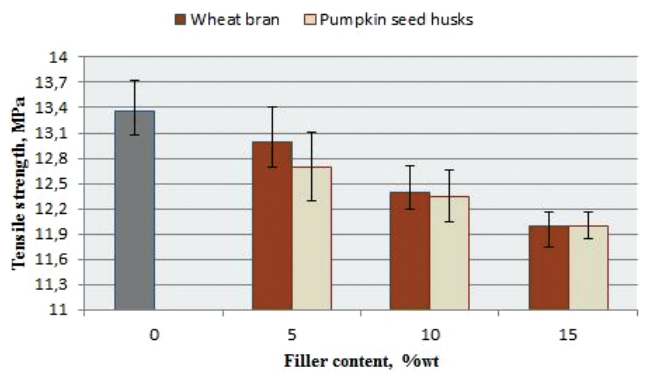

Fig. 4. Tensile strength versus filler content

Figure 5 illustrates the relationship between the tensile stress at yield versus the filler content. In the entire tested range of filler contents, those of wheat bran and pumpkin seed hulls alike, this parameter first decreases and then starts to increase. The addition of a small amount $(10 \mathrm{wt} \%)$ of the filler leads to a decrease in the tensile stress of the specimens by 9.5 $\mathrm{MPa}$ (wheat bran) and by $7.9 \mathrm{MPa}$ (pumpkin seed hulls), which corresponds to, respectively, $57.92 \%$ and $51.82 \%$ decrease in the initial value. The lowest tensile stress can be observed when adding a $10 \mathrm{wt} \%$ content of the wheat bran-based filler. The decrease in the tensile stress may be caused by the loss of the adhesion of small filler particles to the polymer matrix. Adhesion on the polymer-matrix interphase is a crucial factor and often has a decisive effect on the properties of composite materials [23]. Polymer adhesion depends on its adsorption on the filler surface, the wettability of filler grains by filler melt, and the bonding formed between the filler and the polymer.

The relationship between the tensile stress at break and the filler type and content is illustrated in Fig. 6. The diagram clearly demonstrates that the strains decrease with an increase in the filler content, regardless of its type. The decrease in strains versus the filler content is more rapid for polyethylene filled with pumpkin seed hulls. The addition of $15 \mathrm{wt} \%$ of this filler leads to a decrease in the strains by $27.7 \%$, when compared to the strains obtained for the specimens of unfilled polyethylene, i.e. $13 \mathrm{MPa}$. The variations in this parameter for the specimens of polyethylene filled with wheat bran are not that considerable. On adding the highest tested filler content, the strain decreases by $15.4 \%$, so the decrease is almost two times lower than that that observed for the specimens filled with pumpkin seed hulls. The decrease in the strains due to the applied stress with increasing the filler content indicates an increase in rigidity of the material. This trend corresponds with the observed variations in Young's modulus (Fig. 3). This parameter describes eleastic properties of a material, so its increase points to an increase in material's rigidity $[24,25]$.

Figure 7 illustrates the relationship between the tensile strain at yield and the filler types and contents. The diagram shows a decreasing tendency of the tensile strain at yield. The addition of even the smallest filler content results in a rapid decrease in the tensile strain at yield. The addition of $5 \mathrm{wt} \%$ wheat bran-based filler to the polymer matrix leads to a decrease in the maximum tensile strains from $435 \%$ (unfilled polyethylene) to $190 \%$. On increasing this filler's content to $10 \mathrm{wt} \%$, the maximum tensile strain is reduced to $36 \%$; when the filler content is increased to $15 \mathrm{wt} \%$, the tensile strain at yield is decreased by almost 20 times, 
reaching the value of $24 \%$. The pattern of variations in the tensile strain of polyethylene filled with pumpkin seed hulls is similar, and the changes occur even more rapidly. At $5 \mathrm{wt} \%$ pumpkin seed filler, the tensile strain at yield is $98 \%$, which is two times lower than in the case of the bran-based filler; on the addition of $15 \mathrm{wt} \%$ filler, the tensile strain at yield is $17.5 \%$.

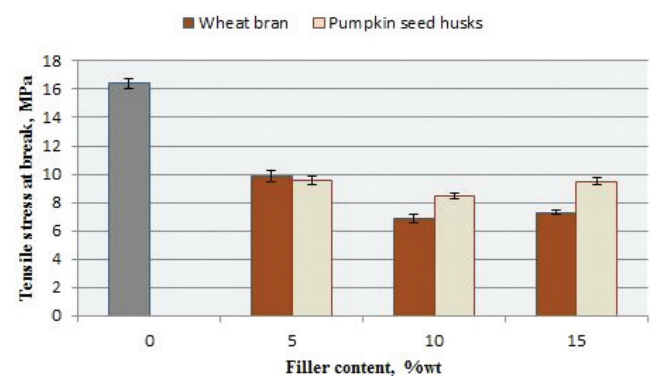

Fig. 5. Tensile stress at break versus filler content

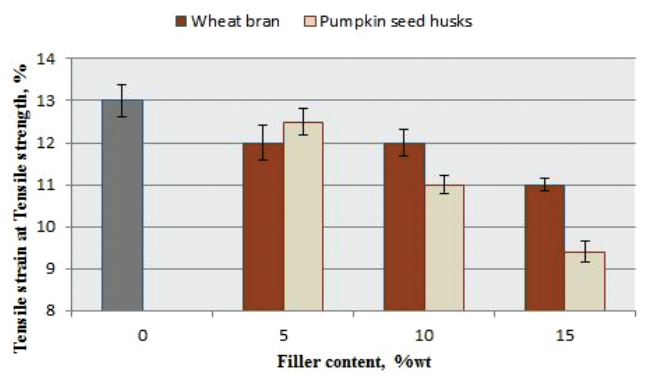

Fig. 6. Tensile strain at tensile strength versus filler content

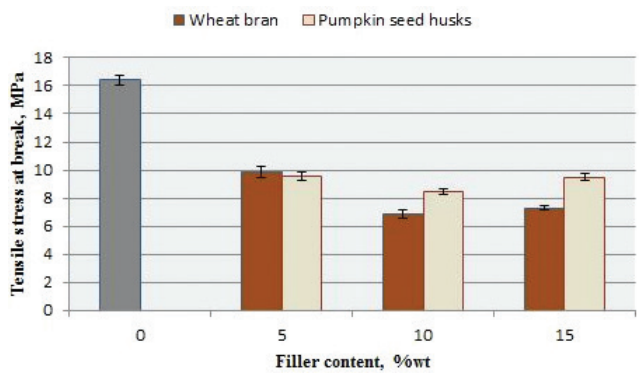

Fig. 7. Tensile strain at yield versus filler content

The decrease in the elasticity of polymer compositions described by tensile strain at yield probably results from the filler grain size. During tension, there occurs cavitation, i.e. the formation of empty spaces at the surface of filler grains undergoing tension. If the grain size is considerable, the above cavities may promote crack initiation leading to the premature formation of a fracture [26, 27]. Moreover, ground pumpkin seed hulls have sharp edges which may damage polymer chains during tensile testing, thus reducing the maximum tensile strain of the polymer composition to an even higher degree.

\subsection{Hardness of the injection molded pieces}

The relationship between Shore hardness D and the filler type and content is illustrated in Fig. 8. The tested fillers exert a different effect on the polymer's properties. The application of $5 \mathrm{wt}$ $\%$ wheat bran filler results in a decrease in the hardness of the entire polymer blend by approx. $3.4 \%$. With a further increase in the wheat bran content, the polymer's hardness is gradually increasing until it reaches $51.24^{\circ} \mathrm{ShD}$; this value is, however, lower than the hardness of the unfilled lowdensity polyethylene $\left(51.68^{\circ} \mathrm{ShD}\right)$ by approx. $0.9 \%$. It can, therefore, be claimed that in the tested 
range of filler content, the wheat bran filler does not have a significant effect on the hardness of the tested polymer blend. In turn, the addition of the pumpkin seed-based filler to the polymer leads to a clear increase in the plastic's hardness. The addition of the smallest tested filler content, i.e. $5 \mathrm{wt} \%$, makes the hardness increase by approx. 3.9\%. With a further increase in the pumpkin seed filler content, the hardness of the polymer blend increases until it reaches $54.73^{\circ} \mathrm{ShD}$ for $15 \mathrm{wt} . \%$ filler, which amounts to an increase by $5.9 \%$ compared to the initial value. It must be underlined that the measured hardness of unfilled polymer is lower than the data provided by the manufacturer, which is probably due to the course of the processing process.

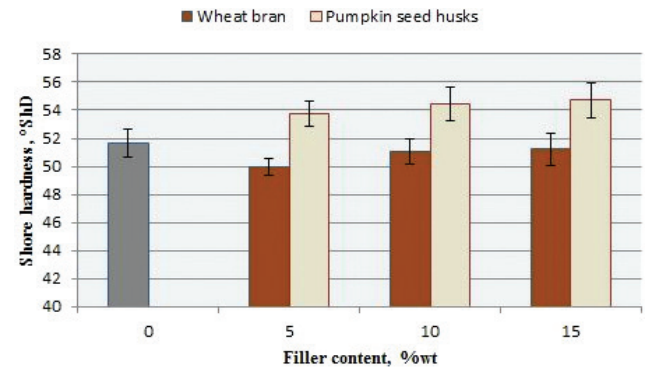

Fig. 8. Shore hardness versus filler content

The hardness of a polymer blend depends on factors such as filler hardness, filler grain size and the interactions on the filler-polymer matrix interphase. Powdered filler grains can act as nucleates in the polymer crystalline phase, which results in an increase in hardness of material [15-17]. Moreover, this can also be due to the fact that, unlike wheat bran, pumpkin seed hulls have a considerable hardness.

\subsection{Morphology of produced polymer blends}

The experiments involved performing microscopic examination of the cross section of the produced polymer blends containing 5,10 and $15 \mathrm{wt} . \%$, respectively. The images of the crosssectional morphology of the produced injection molded pieces are given in Fig. 9.

The examination of the morphology reveals non-uniform distributions of both types of natural fillers. One can observe the presence of varying size particles and agglomerates. The micrometric filler particles, which probably have a higher free surface energy than lowdensity polyethylene, show a tendency for forming agglomerates in such a center (Fig. 9b, c, $\mathrm{e}, \mathrm{f})$. This is undesired because it leads to a decrease in the contact surface between filler and polymer, which, in turn, results in reduced adhesion.

Examining the images one can conclude that the refined filler grains do not have uniform shape or size. This probably results from the initial grain shape of the fillers and their mechanical properties as well as the nature of the grinding process. The grains produced by mechanical grinding have the shape of plates, with one of their dimensions exceeding the tested range. Given its marginal hardness and rigidity, wheat bran tends to roll up. The non-symmetric shape of filler grain and the considerable differences between grain length and width may lead to the asymmetry of properties. 

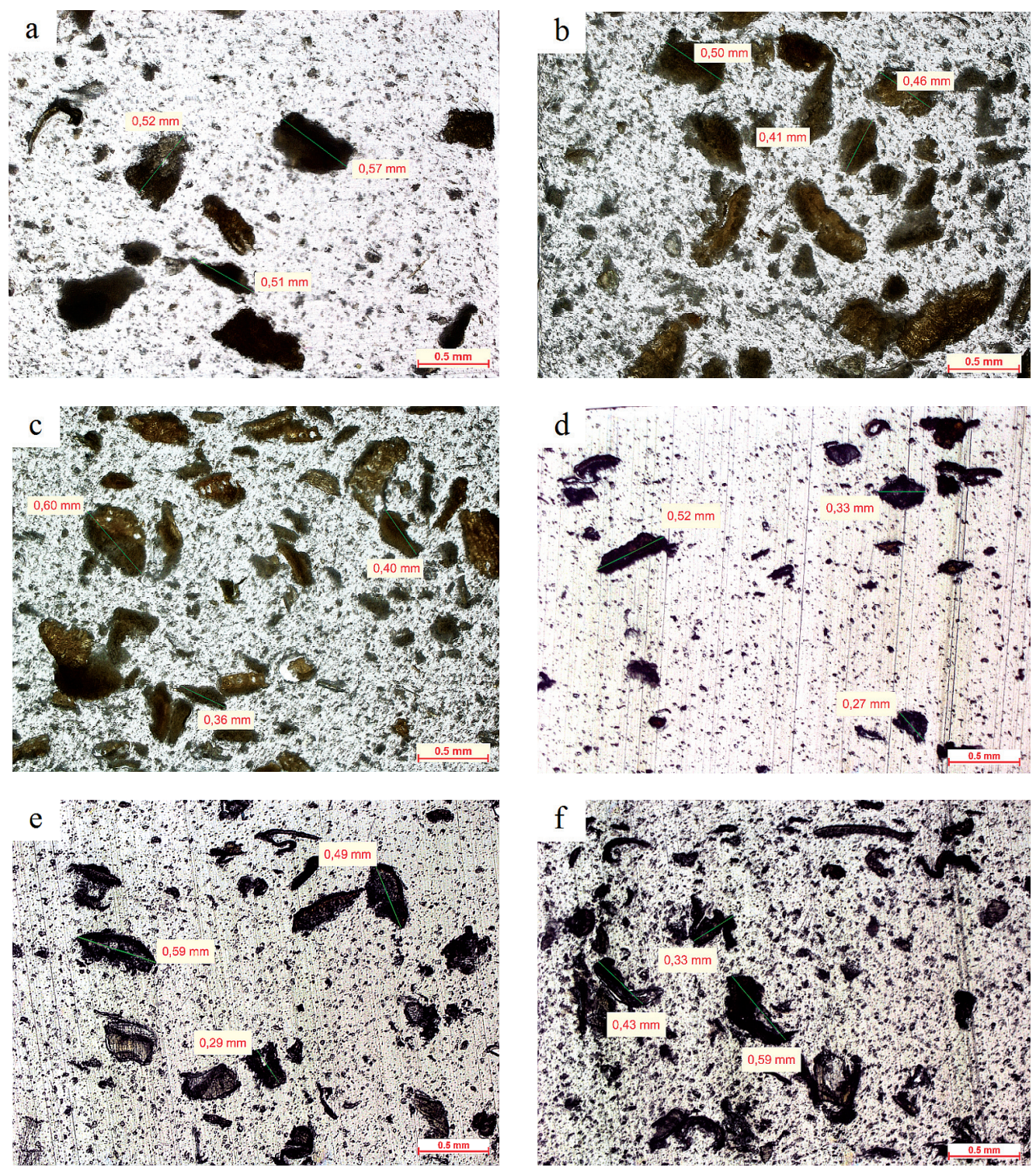

Fig. 9. Images of the cross sections of the tested polymer compounds filled with pumpkin seed hulls $(a-c)$ and wheat bran (d-f) at 5/10/15 wt.\%, respectively

\section{Conclusion}

The exhaustion of petrochemical raw materials and the necessity of $\mathrm{CO}_{2}$ emission reduction led to imposing stringent regulations on environment protection. In effect, the problem of blending polymer matrix materials and fillers based on renewable resources has become one of key research areas. The modification of polymers by means of natural fillers causes many changes in terms of both polymer processing itself and the mechanical 
properties of products and the morphology of their structure. The examination of changes in the properties of thereby modified plastics is significant in terms of their applications.

Natural fillers are widely available and usually come as waste material in different industrial branches, for instance, the food, clothing or woodworking industry. The use of such waste materials is significant in terms of recycling. It must, however, be remembered that the use of natural materials may cause some inconvenience during the processing. The polymer matrix should be suitable for processing at temperatures, which are lower than those of thermal decomposition of organic compounds.

Wheat bran and pumpkin seed hulls can be successfully used as polymer fillers in the injection molding process. The use of these fillers leads to an increase in the hardness of specimens, which is proved by the increase in Young's modulus. However, one can observe a decrease in the tensile strength and the corresponding strain; the maximum tensile strain at yield decreases rapidly, too. The above results and the results reported in the literature demonstrate that this phenomenon is typical of natural fillers. The variations in hardness depend to a greater extent on the filler type and its properties - the filler either increases the specimen hardness (pumpkin seed hulls) or has no significant effect thereon (wheat bran).

\section{References}

[1] Suberlyak O.V., Krasins'kyi V.V., Moravs'kyi V.V., Gerlach H., Jachowicz T., Influence of aluminosilicate filler on the physicomechanical properties of polypropylene-polycaproamide composites, Materials Science, 50, 2014, 296-302.

[2] Alonso M., Velasco J.I., Constrained crystallization and activity of filler in surface modified talc polypropylene composites, European Polymer Journal, 33, 3, 1997, 255-262.

[3] Sterzyński T., Processing and property improvement in isotactic polypropylene by heterogeneous nucleation, Polimery, 45, 11-12, 2000, 786-791.

[4] Sterzyński, T., et al., Trans and Dimethyl quinacridone nucleation of isotactic polypropylene, Polymer Engineering \& Science, 37, 12, 1997, 1917-1927.

[5] Szewczyk P., Nanotechnologia wzbudza duże nadzieje. Przyszłość jest już w drodze, Plastics Review, 11, 2001, 12-14.

[6] Narkis M., Rozenzweig N., Polymer Powder Technology, John Wiley \& Sons, New York 1995.

[7] Khait K., Carr S.H., Solid-State Shear Pulverization, Technomic Publishing Company Inc. Lancaster, PA, USA 2001.

[8] Żenkiewicz M., Richert J., Permeability of polylactide nanocomposite films for water vapour, oxygen, and carbon dioxide, Polymer Testing, 27, 2008, 835-840.

[9] Żenkiewicz M., Richert J., Influence of polymer samples preparation procedure on their mechanical properties, Journal of Achievements in Materials and Manufacturing Engineering, 26, 2, 2008, 155-158.

[10] Stevenson L, Phillips F., O'Sullivan K., Walton J., Wheat bran: its composition and benefits to health, a European perspective, International Journal of Food Sciences and Nutrition, 63, 2012, 1001-1013. 
[11] Chrusciel J., Leśniak E., Fejdys M., Carbofunctional silanes and polysiloxanes. Part I. Applications of carbofumctional silanes, Polimery, 10, 2008, 709-716.

[12] Chrusciel J., Leśniak E., Fejdys M., Carbofunctional silanes and polysiloxanes, Part I., Polimery, 53, 2008, 817-829.

[13] ISO 527-1:2012 Plastics - Determination of tensile properties - Part 1: General principles.

[14] ISO 868:2005 Plastics and ebonite - Determination of indentation hardness by mean of a durometer (Shore hardness).

[15] Paukszta D., Szostak M., Rogacz M., Mechanical properties of polypropylene copolymers composites filled with rapeseed straw, Polimery, 59(2), 2014, 165-169.

[16] Sałasińska K., Osica A., Ryszkowska J., Zastosowanie liści drzew jako wzmocnienia w kompozytach na osnowie recyklatu PE-HD, Polimery, 57(9), 2012, 647.

[17] Sałasińska K., Ryszkowska J., Stabilność wymiarowa, właściwości fizyczne, mechaniczne $i$ cieplne kompozytów polietylenu dużej gęstości z tupinami orzecha ziemnego, Polimery, 58(6), 2013, 461.

[18] Sałasińska K., Ryszkowska J., Kompozyty z odpadów folii PEHD i napelniacza roślinnego w postaci tuski owsa, Przetwórstwo Tworzyw, 2012, 642.

[19] Morreale M., Scaffaro R., Maio A., La Mantia F.P., Effect of adding wood flour to the physical properties of a biodegradable polymer, Composites Part A: Applied Science and Manufacturing, 39(3), 2008, 503-513.

[20] Sahoo S., Misra M., Mohanty A.K., Effect of compatibilizer and fillers on the properties of injection molded lignin-based hybrid green composites, Journal of Applied Polymer Science,127(5), 2013, 4110-4121.

[21] Tajvidi M., Ebrahimi G., Water uptake and mechanical characteristics of natural fillerpolypropylene composites, Journal of Applied Polymer Science, 88(4), 2003, 941-946.

[22] Kurzeja L., Gibas E., Kubica S., Polipropylen z proszkowym napetniaczem weglowym szungitem, Kompozyty, 8(4), 2008, 414-418.

[23] Dányádi L., Móczó J., Pukánszky B., Effect of various surface modifications of wood on the properties of PP/wood composites, Composites Part A: Applied Science and Manufacturing, 41(2), 2010, 199-206.

[24] Rothon R., Mineral Fillers in Thermoplastics: Filler Manufacture and Characterisation, Advances in Polymer Science, 139, 1999, 67-107.

[25] Pukanszky B., Fekete E., Adhesion and Surface Modification, Advances in Polymer Science, 139, 1999, 109-217.

[26] Tjong S., Structural and Mechanical Properties of Polymer Nanocomposites, Materials Science and Engineering: Reports, 53, 2006, 73-197.

[27] Kim G., Michler G., Micromechanical deformation processes in toughened and particle filled semicrystaline polymers. Part 2: Model representation for micromechanical deformation processes, Polymer, 39, 1998, 5699-5703. 